Ichsan Fauzi, Dyah Budibruri Wibaningwati, Sari Anggarawati

Program Studi Agribisnis, Fakultas Pertanian, Universitas Nusa Bangsa, Jl. K.H. Sholeh Iskandar Km. 4, Kelurahan Cibadak, Kecamatan Tanah Sareal, Bogor 16166, Indonesia

e-mail: ichsanfauzi28@gmail.com e-mail korespondensi: dyah_buds@yahoo.co.id e-mail: sarianggarawati@gmail.com

\section{STRATEGI USAHA TERNAK MANDIRI DI DESA CIMAHPAR, KAMPUNG BELENTUK KECAMATAN BOGOR UTARA}

\author{
(Independent Livestock Business Strategy in Cimahpar \\ Village, Belentuk Village, Bogor Utara District)
}

ISSN: 2721-8589 (media online) ISSN: 2721-8597 (media cetak)

\section{AGRISINTECH}

Journal of Agribusiness and

Agrotechnology

Vol. 1 No. 1 April 2020

\begin{abstract}
The most popular livestock business is broiler chicken farming because it has a high demand. Bogor City is one of the broiler chicken meat production centres in West Java. This study aims to (1) conduct a feasibility analysis of the business of broiler chicken farming from the financial aspect (2) identify problems in broiler farming using SWOT Analysis (3) business continuity strategy. This research was conducted from June to July 2019 using primary and secondary data. The analysis used is qualitative and quantitative analysis, where the qualitative analysis is done descriptively describing the business system and non-financial aspects as well as the quantitative analysis used, namely the financial feasibility analysis. Based on the results of the SWOT matrix analysis SGF88 broiler chicken farms are in the Quadrant IV position, wherein that position the recommended strategy is to rescue as soon as possible so as not to cause even greater losses. The financial aspects of the SGF88 broiler chicken farming business are not feasible to proceed, because seen from the $R / C$ ratio of minus 0.02 , Net $B / C$ of 0.98 , and PP of minus 52.24 periods. The results of switching value analysis show that broiler chicken farming is very sensitive to a decrease in feed prices by $1 \%$ compared to the sensitivity of an increase in selling prices by $18 \%$.
\end{abstract}

Keywords: Strategy, livestock business

\begin{abstract}
ABSTRAK
Usaha peternakan yang banyak diminati adalah peternakan ayam broiler karena memiliki permintaan yang tinggi. Kota Bogor merupakan salah satu daerah sentra produksi daging ayam broiler di Jawa Barat. Penelitian ini bertujuan untuk (1) Melakukan analisis kelayakan usaha peternakan ayam broiler dari aspek finansial (2) Mengidentifikasi permasalahan dalam usahatani peternakan ayam broiler menggunakan Analisis SWOT (3) Strategi keberlangsungan usaha. Penelitian ini dilakukan pada bulan Juni sampai dengan Juli 2019 dengan menggunakan data primer dan sekunder. Analisis yang digunakan yaitu analisis kualitatif dan kuantitatif, dimana analisis kualitatif dilakukan secara deskriptif menggambarkan sistem usaha dan aspek nonfinansial serta analisis kuantitatif yang digunakan yaitu analisis kelayakan finansial. Berdasarkan hasil analisis Matrik SWOT peternakan ayam potong broiler SGF88 berada di posisi Kuadrant IV, dimana dalam posisi tersebut strategi yang dianjurkan adalah melakukan penyelamatan secepatnya sehingga tidak menimbulkan kerugian yang semakin membesar. Aspek finansial usaha peternakan ayam broiler SGF88 tidak layak untuk dilanjutkan, karena dilihat dari nilai R/C rasio sebesar minus 0,02, Net B/C sebesar 0,98, dan PP sebesar minus 52,24 periode. Hasil analisis switching value menunjukkan usaha peternakan ayam broiler sangat sensitif terhadap penurunan harga pakan sebesar $1 \%$ dibandingkan dengan sensitifitas kenaikan harga jual sebesar $18 \%$.
\end{abstract}

Kata Kunci: Strategi, usaha peternak 


\section{PENDAHULUAN}

Peternakan merupakan salah satu sub pertanian yang memiliki peranan cukup penting dalam memberikan kontribusi yang cukup besar terhadap perekonomian ini. Sub peternakan merupakan bagian dari pertanian yang sangat potensial untuk dikembangkan dalam menyediakan pangan hewani berupa daging, susu, serta telur yang benilai gizi tinggi. Sub peternakan dapat meningkatkan pendapatan masyarakat khususnya peternak, serta memperluas kesempatan kerja. Salah satu komoditi peternakan yang banyak dikonsumsi oleh masyarakat dalam rangka pemenuhan kebutuhan protein adalah daging. Kebutuhan masyarakat terhadap daging seperti halnya produk ternak lainnya mengalami peningkatan seiring dengan meningkatnya jumlah penduduk, pendapatan dan taraf hidup masyarakat. Upaya pemenuhan protein hewani dan peningkatan pendapatan peternak, pemerintah telah berupaya meningkatkan hasil produksi yang bersumber dari usaha ternak, diantaranya adalah ayam ras pedaging atau ayam broiler. Produk broiler tergolong produk bernilai ekonomi tinggi yang memerlukan penanganan cepat dan tepat melalui integrasi atau koordinasi vertikal (Saptana, 2013).

Populasi ayam broiler di Indonesia saat ini mencapai 1.891.434.612 ekor, meningkat sekitar $40,7 \%$ dari populasi lima tahun silam yang hanya: 1.344.191.104 ekor (Badan Pusat Statistik, 2018). Pemerintah juga berusaha untuk meningkatkan kinerja perunggasan dengan cara memperbaiki iklim investasi, peningkatan pembangunan infrastruktur dan ketersediaan sumberdaya yang terlatih sehingga peternak ayam broiler dikatakan layak untuk usaha. Selain itu, kelayakan usaha peternakan ayam broiler harus layak dari aspek sosial ekonomi karena tidak merugikan lingkungan sekitar (Karmidi, 2012). Hal inilah yang dapat menjadi daya tarik bagi masyarakat dan investor untuk berkecimpung di usaha ternak ayam broiler.

Peternakan ayam broiler SGF8 merupakan peternakan ayam mandiri yang bergerak di bidang peternakan ayam potong atau ayam broiler. Peternakan ayam broiler SGF88 masih berada ditingkat usaha skala kecil dikarenakan keterbatasan modal (Sudaryanto, Ragimun, \& Wijayanti, 2014) dan hanya fokus di pembesaran ayam broiler untuk dijual kembali ke pasar sebagai ayam potong. Status petani mandiri yang mana suplai ketersediaan bibit DOC (Day-oldchicken), pakan, vitamin, vaksin dan obatobatan masih sangat bergantung dengan perusahaan besar dimana perusahaan tersebut adalah perusahaan yang menjadi pesaing peternak itu sendiri, dimana perusahaan bergerak dibidang yang sama. Upaya pengembangan lingkup bisnisnya, perusahaan tersebut memproduksi telur, bibit atau DOC, pakan, sampai pembesaran ayam broiler yang nantinya siap dipanen dan dilempar ke pasaran. Skala dan lingkup pengembangan bisnis yang besar dikhawatirkan dapat memonopoli pasar, baik dari segi harga, ketersediaan stok ayam.

Berdasarkan uraian tersebut, dirasakan perlu melakukan penelitian dengan tujuan mengetahui masalah yang terdapat pada usahatani peternakan ayam broiler SGF88, mengetahui kelayakan usahatani peternakan ayam broiler SGF88 dari sisi finansial, serta merumuskan strategi kelangsungan usaha peternakan ayam broiler SGF88. 


\section{METODE PENELITIAN}

Penelitian ini disusun berdasarkan kunjungan langsung yang telah dilakukan selama satu bulan, yaitu sejak tanggal 1 Juni sampai dengan tanggal 30 Juni 2019 di peternakan SGF88 yang belokasi di Kampung Pasir Jambu, Kecamatan Bogor Utara, Kota Bogor, Provinsi Jawa Barat. Peternakan ayam SGF88 dipimpin oleh Bapak Soegeng Pribadi. Selain itu, dimana Kota Bogor dan Kabupaten Bogor merupakan sentra peternakan ayam broiler terbesar di Provinsi Jawa Barat. Lokasi ini dipilih karena lokasinya strategis dan berada di tengah-tengah antara perbatasan Kota dan Kabupaten Bogor.

Data yang digunakan dalam penelitian ini berupa data primer dan data sekunder. Data primer diperoleh melalui wawancara dengan pengawas dan selaku pembimbing lapangan yaitu Bapak Joko Suprasetyo dan karyawan SGF88. Data sekunder diperoleh melalui studi kasus, buku, majalah, instansi terkait seperti Badan Pusat Statistik (BPS), Dinas Peternakan, dan data yang ada di peternakan ayam SGF88. Data yang diperoleh dapat dianalisis secara kualitatif dan kuantitatif. Deskripsi terhadap bisnis peternakan ayam ini akan dianalisis secara kualitatif. Sementara analisis kelayakan finansial akan dianalisis secara kuantitatif, kemudian hasilnya akan dijelaskan secara kualitatif.

Metode analisis yang digunakan dalam penelitian pengembangan bisnis ini adalah $\mathrm{R} / \mathrm{C}$ rasio yaitu perbandingan antara penerimaan kotor yang dihasilkan dengan biaya yang dikeluarkan dalam setiap produksi, Net B/C ratio antara manfaat bersih yang bernilai positif dengan manfaat bersih yang bernilai negatif (Nurmalina, R., Sarianti, T.,\& Karyadi, 2009), Payback Periods suatu periode yang diperlukan untuk menutup kembali pengeluaran investasi (initial cash investment) dengan menggunakan aliran kas (Umar, 2007), sensitivitas yaitu menentukan bagaimana distribusi pengembalian yang mungkin untuk usaha dipengaruhi oleh perubahan salah satu input (Saputra, 2011), dan SWOT yaitu identifikasi berbagai faktor secara sistematis untuk merumuskan strategi organisasi (Rangkuti, 2006) atau strategi peternakan ayam SGF88.

\section{HASIL DAN PEMBAHASAN}

Berdasarkan aspek finansial, peternakan ini merupakan usaha dalam bidang agribisnis ayam broiler yang menggunakan modal sendiri dalam menjalankan usahanya. Skala usaha peternakan ayam broiler ini adalah skala usaha peternakan rakyat dengan jumlah ayam yang dipelihara sebanyak 13.000 ekor per periode. Pada penelitian ini analisis kelayakan dilakukan untuk mengetahui kelayakan investasi usaha peternakan. Berikut komponen arus kas (cashflow) yang ada dalam usaha peternakan ayam broiler di lokasi penelitian:

\section{Arus Penerimaan (Inflow) \\ a. Penerimaan Penjualan}

Penerimaan penjualan yang diperoleh peternakan berasal dari penjualan ayam broiler, penjualan kotoran ayam. Penjualan ayam dihitung dari 13.000 DOC yang dipelihara dikurangi dengan angka mortalitas, dikalikan dengan harga Kapasitas pemeliharaan ayam broiler per periodenya adalah 13.000 ekor. Pada setiap pembelian DOC sebanyak 13.000 ekor, pemilik peternakan memperoleh DOC sebanyak 13.260 ekor. Hal ini disebabkan karena setiap pembelian 1 box DOC terdiri dari 102 DOC sehingga dengan pembelian DOC sebanyak 130 box maka DOC yang diperoleh sebanyak 13.260 DOC. Selain itu, peternakan ayam broiler ini juga menggunakan batas angka mortalitas dengan riwayat kematian ayam di peternakan ini maka angka mortalitas 
setiap periode adalah maksimal $4 \%$ (Rasyaf, 2008), namun pada kenyatanya angka mortalitas yang terjadi dilapangan melebihi 5 persen. Pemanenan dilakukan saat ayam berumur 27 hari, bobot ratarata mencapai 1,5 kilogram per ekornya. Satu tahun terjadi enam kali masa panen.
Pembeli langsung datang ke kandang untuk membeli ayam broiler dari peternakan ini dan dibantu oleh penanggung jawab lapang. Penerimaan penjualan ayam broiler hidup di peternakan ayam broiler ini dapat dilihat pada Tabel 1.

Tabel 1. Penerimaan penjualan ayam broiler hidup dalam satu tahun di SGF88

\begin{tabular}{clcccc}
\hline Periode & \multicolumn{1}{c}{ Bulan } & Panen (ekor) & $\begin{array}{c}\text { Bobot } \\
\text { Panen } \\
\text { (kg/ekor) }\end{array}$ & $\begin{array}{c}\text { Harga (Rp/ } \\
\text { ekor) }\end{array}$ & $\begin{array}{c}\text { Penerimaan } \\
\text { (Rp) }\end{array}$ \\
\hline 1 & Agustus-September 2018 & 11660 & 1.6 & 18.000 & $335,808,000$ \\
2 & Oktober-November 2018 & 12460 & 1.5 & 19.000 & $355,110,000$ \\
3 & Desember-Januari 2018- & 12260 & 1.3 & 19.000 & $302,822,000$ \\
4 & Februari-Maret 2019 & 11910 & 1.8 & 14000 & $300,132,000$ \\
5 & April-Mei 2019 & 12260 & 1.5 & 19000 & $349,410,000$ \\
6 & Juni-Juli 2019 & 12090 & 1.5 & 18500 & $335,497,500$ \\
\hline
\end{tabular}

Sumber: Hasil pengolahan data primer (2019)

Berdasarkan perhitungan penerimaan pada Tabel 1 dapat dilihat bahwa penerimaan yang berasal dari penjualan ayam hidup selama satu tahun adalah sebesar Rp1.978.779.500,00. Hasil tersebut didapat dari perkalian antara jumlah ayam broiler yang dipanen per periode setelah dikurangi angka mortalitas di atas 5\% dan dengan bobot panen yang bervariasi setiap periode per ekor dengan harga jual yang selalu update setiap harinya di internet, dengan jumlah periode yang dilakukan dalam satu tahun yaitu enam periode.

\section{b. Penerimaan Penjualan Kotoran Ayam}

Penerimaan peternakan ayam broiler ini juga bersumber dari hasil penjualan kotoran ayam yang dijual dengan harga Rp4.000,00 per karung atau per 50 kilogram. Setiap periode rata-rata menghasilkan 160 karung kotoran ayam. Pembeli datang dan mengambil sendiri kotoran ayam yang akan dibelinya. Penerimaan peternakan yang berasal dari penjualan kotoran ayam dapat dilihat pada Tabel 2.

Tabel 2. Penerimaan per periode kotoran ayam di SGF88

\begin{tabular}{clccc}
\hline Periode & \multicolumn{1}{c}{ Bulan } & $\begin{array}{c}\text { Kotoran per } \\
\text { periode (Karung) }\end{array}$ & $\begin{array}{c}\text { Harga } \\
\text { (Rp/karung) }\end{array}$ & $\begin{array}{c}\text { Penerimaan per periode } \\
\text { (Rp) }\end{array}$ \\
\hline 1 & Agustus-September 2018 & 160 & 4000 & 640.000 \\
2 & Oktober-November 2018 & 160 & 4000 & 640.000 \\
3 & Desember-Januari 18-19 & 160 & 4000 & 640.000 \\
4 & Februari-Maret 2019 & 160 & 4000 & 640.000 \\
5 & April-Mei 2019 & 160 & 4000 & 640.000 \\
6 & Juni-Juli 2019 & 160 & 4000 & 640.000 \\
\hline \multicolumn{4}{c}{ Total penerimaan penjualan kotoran ayam } \\
\hline
\end{tabular}

Sumber: Hasil pengolahan data primer (2019)

Fauzi, I., Wibaningwati, D.B., Anggarawati, S.: Strategi usaha ternak mandiri di Desa Cimahpar, 
2. Arus Biaya (Outflow)

Outflow adalah aliran kas yang dikeluarkan usaha. Outflow usaha peternakan ayam broiler dibagi menjadi dua yaitu biaya investasi dan biaya operasional. Outflow menunjukkan pengeluaran biaya-biaya yang mengakibatkan pengurangan kas pada aliran cashflow. Pengurangan ini diakibatkan biaya-biaya yang harus dikeluarkan untuk membiayai kegiatan usaha seperti kegiatan investasi dan kegiatan operasional usaha. Biaya investasi dikeluarkan pada saat awal pendirian usaha dan kemudian dilakukan re-investasi jika umur ekonomis telah habis sementara usaha masih terus berjalan. Sedangkan biaya operasional usaha adalah biaya yang dikeluarkan selama proses produksi berlangsung yang terdiri dari biaya tetap dan biaya variabel (Setiawan, 2016), dikarenakan lahan, kandang dan alat-alat masuk kedalam beban sewa maka biaya investasi pada peternakan ayam SGF88 tidak dimasukan.

\section{a. Biaya Operasional}

Biaya operasional usaha peternakan ayam broiler dibagi menjadi dua jenis yaitu biaya tetap dan biaya variabel.

\section{(1) Biaya tetap}

Biaya tetap adalah biaya yang dikeluarkan yang besarnya tidak dipengaruhi langsung oleh jumlah produksi. Biaya tetap yang dikeluarkan oleh usaha peternakan ayam broiler ini terdiri dari gaji tenaga kerja, biaya listrik, tunjangan hari raya, CSR, biaya panen, kayu bakar, dan sekam.

\section{(a) Gaji tenaga kerja}

Tenaga kerja yang dipekerjakan berjumlah empat orang. Terdiri dari satu orang pengawas dan tiga orang anak buah kandang. Namun biaya tenaga kerja yang dimasukkan ke dalam biaya tetap hanya pengawas yang mana gaji sudah tetap setiap periode sebesar Rp2.000.000,00, sehingga dalam satu tahun atau enam periode menjadi sebesar Rp12.000.000,00.

(b) Biaya listrik

Biaya listrik yang dikeluarkan per periode kurang lebih Rp1.000.000,00 per periode sehingga dalam satu tahun biaya listrik yang dikeluarkan adalah sebesar Rp6.000.000,00.

(c) Biaya CSR

Biaya sosial ini merupakan biaya yang dikeluarkan oleh peternakan ayam broiler ini sebagai kontribusi untuk masyarakat sekitar kandang. Setiap periode produksi, pemilik mengeluarkan Rp1.000.000,00 untuk kegiatan masyarakat sekitar peternakan.

(d) Tunjangan hari raya

Biaya tunjangan hari raya yang dikeluarkan untuk tenaga kerja di peternakan ayam broiler ini kurang lebih Rp3.000.000,00 per tahun untuk tiga orang tenaga kerja.

(e) Sewa kandang dan alat- alat

Biaya sewa kandang dan alat- alat yang dikeluarkan sebagai sarana produksi pada peternakan ayam broiler ini per tahun adalah sebesar Rp50.000.000,00 untuk biaya penyusutan kandang dan lahan tidak dimasukan karena menjadi tanggung jawab pemilik lahan.

\section{(2) Biaya variabel}

Biaya variabel yang dikeluarkan pada usaha peternakan ayam broiler ini terdiri dari biaya DOC, pakan, obat-obatan, sekam, dan kayu bakar. Berikut penjelasan masing-masing komponen biaya variabel usaha peternakan ayam broiler SGF88.

(a) Day Old Chick (DOC)

Harga DOC diasumsikan sama pada setiap tahunnya yaitu sebesar Rp4.000,00 per ekor, yang merupakan harga rata-rata DOC yang sering digunakan oleh peternakan. 
(b) Tenaga kerja

Untuk biaya tenaga kerja ABK (Anak Buah Kandang) dimasukan kedalam biaya variable dikarenakan besaran gaji akan didapat berdasarkan jumlah ayam di kelola oleh masing-masing ABK. Sehingga semakin besar tingkat mortalitasnya maka gajinya akan semakin kecil begitu juga sebaliknya. Besaran perhitungan gaji ABK adalah jumlah ayam yang hidup saat panen dikalikan dengan Rp500,00. Ratarata besarannya sekitar Rp6.043.750,00 dan jika dikalikan 6 periode atau satu tahun menjadi sebesar Rp 36.262.500,00.

(c) Pakan

Harga pakan diasumsikan mengunakan tingkat harga tertinggi yaitu sebesar Rp7.408,00 per kg, untuk menghasilkan $1,5 \mathrm{~kg}$ ayam maka dibutuhkan $2,5 \mathrm{~kg}$ pakan per periode, maka biaya pakan untuk satu ekor DOC yaitu $2,5 \mathrm{~kg}$ per ekor dikalikan harga pakan Rp7.408,00 yaitu sebesar Rp18.520,00.

(d) Obat-obatan

Harga obat-obatan diasumsikan sama tiap periodenya untuk jumlah DOC sebanyak 13.000 ekor. Setiap DOC menghabiskan biaya sebesar Rp704,00 maka biaya obat-obatan yang dikeluarkan peternakan ini per tahun yaitu sebesar Rp56.004.000,00.

(e) Biaya sekam

Kebutuhan sekam untuk satu kali produksi sebanyak 568 karung. Biaya yang dikeluarkan untuk pembelian sekam adalah Rp7.000,00 per karung, sehingga total biaya yang dikeluarkan untuk sekam per tahun adalah sebesar Rp23.868.000,00. (f) Biaya kayu bakar

Pemanas kandang yang digunakan pada peternakan ayam broiler ini adalah kayu bakar yang dimasukkan ke drum. Kebutuhan biaya untuk pemanas kandang ini adalah Rp3.750.000,00 per periode, sehingga dalam satu tahun biaya yang dikeluarkan untuk pemanas kandang yaitu Rp22.500.000,00.

\section{Analisis Laba Rugi}

Usaha ayam broiler ini tidak ada biaya penyusutan dan nilai sisa dikarenakan lahan, kandang dan alat- alat masuk kedalam beban sewa dan menjadi tanggung jawab pemilik lahan. Total penerimaan selama satu tahun sebesar Rp1.982.619.500,00 dan total pengeluaran selama satu tahun sebesar Rp2.021.314.512,00. Total laba bersih yang dihasilkan sebesar minus Rp38.695.012,00.

\section{Analisis Kriteria Kelayakan Investasi 1). $R / C$ rasio}

Pada usaha peternakan ayam broiler ini nilai $\mathrm{R} / \mathrm{C}$ rasio adalah minus 0,02 yang berarti usaha tersebut dapat dikatakan tidak menguntungkan untuk dijalankan.

\section{2). Net Benefit Cost Ratio (Net B/C)}

Pada usaha peternakan ayam broiler ini nilai Net B/C adalah 0,98 yang berarti usaha peternakan ayam broiler ini tidak layak untuk dijalankan karena nilai Net B/C $<1$.

\section{3). Payback Periode (PP)}

Pada usaha peternakan ayam broiler ini nilai Payback Period yang diperoleh sebesar minus 52,24 artinya modal investasi tidak kembali, sehingga usaha ini tidak layak dijalankan karena Payback Period (PP) yang dihasilkan minus. 
Tabel 3. Hasil analisis kelayakan investasi peternakan ayam broiler di SGF88

\begin{tabular}{lrc}
\hline Kriteria Kelayakan & Hasil Penilaian & Keterangan \\
\hline R/C rasio & $(0,02)$ & Tidak Layak \\
NET B/C & 0,98 & Tidak Layak \\
PP & $(52,24)$ & Tidak Layak \\
\hline
\end{tabular}

Sumber: Hasil pengolahan data primer (2019)

Berdasarkan hasil dari kelayakan investasi yaitu R/C rasio, Net B/C, dan payback period (PP) seperti yang ditunjukkan pada Tabel 3. Maka dapat dikatakan bahwa usaha peternakan ayam broiler ini tidak layak untuk dijalankan, karena belum memenuhi kriteria kelayakan, R/C rasio kurang dari satu, Net B/C lebih besar dari satu dan payback period (PP) lebih kecil dari umur bisnis.

\section{Analisis Switching Value}

Analisis switching value digunakan untuk mengukur perubahan maksimum dari perubahan suatu komponen inflow ataupun outflow yang masih dapat ditoleransi agar usaha masih tetap layak untuk dijalankan. Perubahan ini ditentukan dengan menguji secara cobacoba sampai berapa \% perubahan yang bisa terjadi dengan masih memenuhi kriteria minimum kelayakan investasi seperti R/C rasio lebih dari satu, Net B/C sama dengan satu, dan PP kurang dari umur bisnis. Nilai peubah dalam analisis ini adalah perubahan terhadap penurunan harga pakan dan menaikan harga jual ayam broiler. Pertimbangan penggunaan nilai pengganti (switching value) kenaikan harga pakan dikarenakan pakan merupakan komponen biaya terbesar dari keseluruhan biaya yang dikeluarkan peternakan dan begitu pula penurunan harga jual ayam broiler (Sianturi \& Sarianti, 2011). Selain itu, harga pakan dari perusahaan yang fluktuasi ini membuat pihak peternakan perlu memperhatikan komponen ini, dikarenakan input pakan merupakan komponen utama dalam kegiatan operasional produksi ayam broiler, karena ayam broiler sangat membutuhkan pakan untuk tumbuh dan berkembang biak. Menaikan harga jual ayam dilakukan untuk melihat berapa kenaikan harga jual ayam yang dapat ditoleransi. Hasil analisis perhitungan switching value dapat dilihat pada Tabel 4.

Tabel 4. Hasil Analisis Perhitungan Switching Value pada peternakan SGF88

\begin{tabular}{lc}
\hline Kriteria & Persentase (\%) Penurunan Harga \\
\hline Pakan & 1 \\
Menaikan Harga Jual & 18 \\
\hline Sumber: Hasil pengolahan data primer (2019) &
\end{tabular}


Berdasarkan analisis switching value terhadap penurunan harga pakan, dan menaikan harga jual, maka dapat dilihat bahwa batasan terhadap kenaikan harga pakan 1 persen, serta menaikan harga jual ayam 18 persen. Hal ini menunjukkan bahwa kenaikan harga pakan dan penurunan harga jual ayam sangat sensitif terhadap usaha peternakan ayam broiler. Jika usaha menghadapi kondisi perubahan melebihi batas tersebut maka usaha tidak layak untuk terus dijalankan secara finansial.

\section{ANALISIS SWOT}

SWOT adalah singkatan dari lingkungan Internal Strengths dan Weaknesses serta lingkungan eksternal Opportunities dan Threaths yang dihadapi. Analisis SWOT selanjutnya akan membandingkan lingkungan internal terhadap lingkungan eksternal. Analisis SWOT dilakukan melalui serangkaian perhitungan yang dikenal dengan perhitungan IFAS (internal factor analysis strategy), membahas pengambilan keputusan, permodalan, lokasi, status lahan, pengalaman usaha, teknik produksi, suplai DOC, dan biaya. Selanjutnya EFAS (exsternal analysis strategy), membahas tentang pangsa pasar, permintaan pasar dan faktor- faktor lainya yang bersifat kurang menguntungkan. Berikut cara menghitung IFAS DAN EFAS dengan memperhitungkan nilai bobot dan rating faktor.

Tabel 5. Hasil matrik SWOT IFAS pada peternakan SGF88

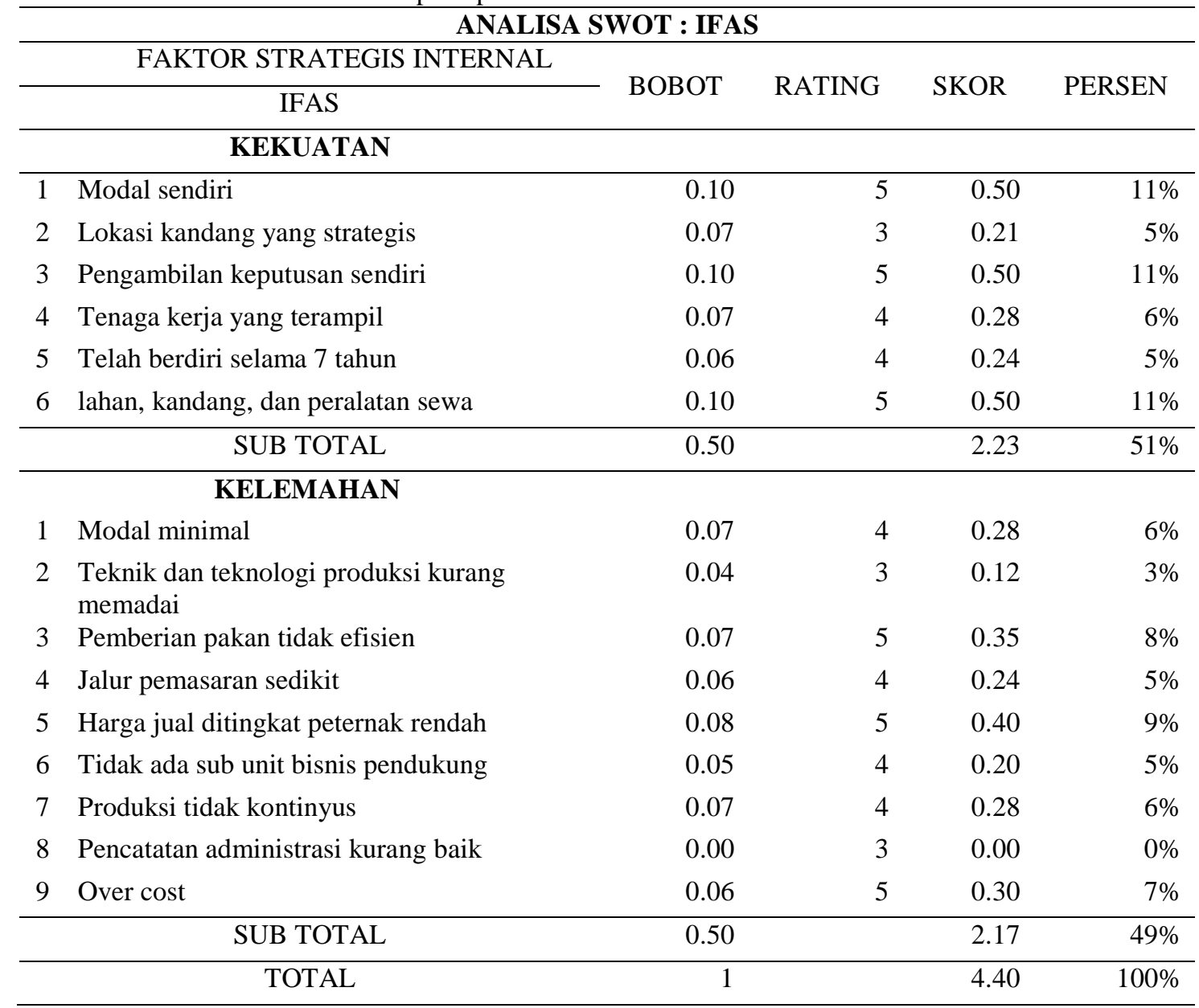

Sumber: Hasil pengolahan data primer (2019)

Fauzi, I., Wibaningwati, D.B., Anggarawati, S.: Strategi usaha ternak mandiri di Desa Cimahpar,

Kampung Belentuk, Kecamatan Bogor Utara. (1-14) 
Tabel 6. Hasil matriks SWOT EFAS pada peternakan SGF88

\begin{tabular}{|c|c|c|c|c|c|}
\hline \multicolumn{2}{|r|}{$\begin{array}{l}\text { FAKTOR STRATEGIS } \\
\text { EKSTERNAL }\end{array}$} & \multirow[t]{3}{*}{ BOBOT } & \multirow[t]{3}{*}{ RATING } & \multirow[t]{3}{*}{ SKOR } & \multirow[t]{3}{*}{ KETERANGAN } \\
\hline & EFAS & & & & \\
\hline \multicolumn{2}{|r|}{ PELUANG } & & & & \\
\hline 1 & Pangsa pasar masih luas & 0.10 & 5 & 0.50 & $13 \%$ \\
\hline 2 & Permintaan tinggi & 0.10 & 3 & 0.30 & $8 \%$ \\
\hline 3 & Adanya pemasok tetap & 0.08 & 2 & 0.16 & $4 \%$ \\
\hline 4 & Adanya pelanggan tetap & 0.07 & 3 & 0.21 & $5 \%$ \\
\hline 5 & Harga ditingkat konsumen tinggi & 0.10 & 3 & 0.30 & $8 \%$ \\
\hline 6 & $\begin{array}{l}\text { Terjalinnya kerja sama dengan } \\
\text { pihak luar }\end{array}$ & 0.05 & 3 & 0.15 & $4 \%$ \\
\hline & SUB TOTAL & 0.50 & & 1.62 & $42 \%$ \\
\hline \multicolumn{6}{|c|}{ ANCAMAN } \\
\hline 1 & $\begin{array}{l}\text { Ancaman secara fisik dan mental } \\
\text { dalam Pengelolaan } \\
\text { lahan }\end{array}$ & 0.01 & 1 & 0.01 & $5.0 \%$ \\
\hline 2 & $\begin{array}{l}\text { Intervensi pihak- pihak luar dalam } \\
\text { pengelolaan lahan }\end{array}$ & 0.01 & 1 & 0.01 & $0 \%$ \\
\hline 3 & Adanya pesaing perusahaan besar & 0.10 & 5 & 0.50 & $10 \%$ \\
\hline 4 & Terdapat hewan predator & 0.03 & 2 & 0.06 & $2 \%$ \\
\hline 5 & Harga pakan tinggi & 0.10 & 5 & 0.50 & $13 \%$ \\
\hline 6 & $\begin{array}{l}\text { Harga jual ditingkat peternak } \\
\text { rendah }\end{array}$ & 0.10 & 5 & 0.50 & $11 \%$ \\
\hline 7 & Ketergantungan suplai DOC & 0.10 & 5 & 0.50 & $13 \%$ \\
\hline 8 & Cuaca yang tidak menentu & 0.05 & 4 & 0.20 & $5 \%$ \\
\hline & SUB TOTAL & 0.50 & & 2.28 & $58 \%$ \\
\hline & TOTAL & 1 & & 3.90 & $100 \%$ \\
\hline
\end{tabular}

Sumber: Hasil pengolahan data primer (2019)

Berdasarkan tabel IFAS (Internal Factor Strategy) dan EFAS (Exsternal Factor Startegy) diperoleh hasil scoring factor Internal dan eksternal yaitu,
Kekuatan (2,23), Kelemahan (2,17), Peluang (1,62), dan Ancaman (2,28). Berikut adalah tabel Matrik IFAS dan EFAS.

Tabel 7. Hasil analisis matrik SWOT IFAS dan EFAS pada peternakan SGF88

\begin{tabular}{ccc}
\hline INTERNAL & KEKUATAN \\
EKSTERNAL & $\begin{array}{c}\text { KELEMAHAN } \\
\text { (WTRENGHT }(\mathrm{S}))\end{array}$ \\
\hline PELUANG & Strategi (S-O) & Strategi (W-O) \\
(OPPORTUNITIES (O)) & $2,23+1,62=3,85$ & $2,17+1,62=3,79$ \\
ANCAMAN & Strategi $(\mathrm{S}-\mathrm{T})$ & Strategi (W-T) \\
(THREATS $(\mathrm{T}))$ & $2,23+2,28=4,51$ & $2,17+2,28=4,45$ \\
\hline
\end{tabular}

Sumber: Hasil pengolahan data primer (2019) 
Setelah proses perhitungan untuk mendapatkan bobot IFAS dan EFAS dilakukan, langkah selanjutnya adalah merumuskan strategi dalam bentuk penentuan koordinat dalam diagram analisis SWOT dan menyusun faktorfaktor strategis perusahaan dalam matriks SWOT. Penentuan koordinat dalam diagram analisis SWOT berfungsi untuk menentukan posisi strategi perusahaan apakah terletak di kuadran I, II, III atau IV. Hal ini berfungsi untuk mengidentifikasi apakah strategi perusahaan bersifat Agresif, Diversifikasi, Turn-Aroud atau Defensif. Gambar 1 merupakan perhitungan koordinat strategi perusahaan berdasarkan perhitungan bobot pada matriks IFAS dan EFAS.

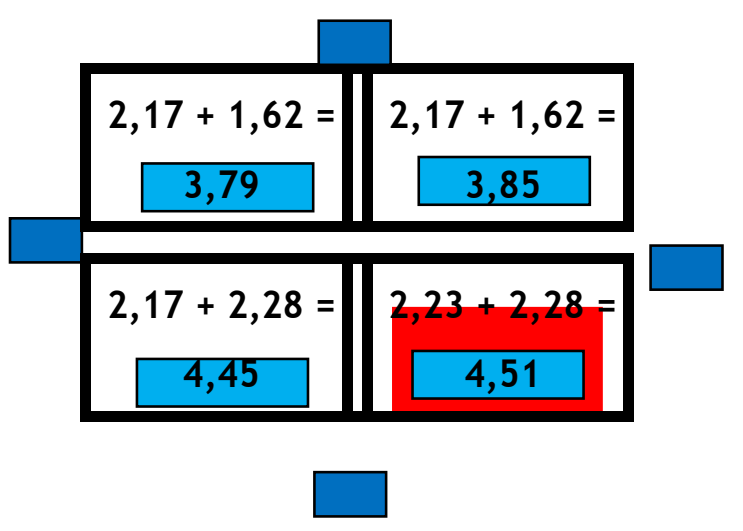

Gambar 1. Diagram Strategi Matriks SWOT

Berdasarkan data tabel turunan Strategi SWOT diatas, dimana peternakan ayam potong broiler SGF88 berada di posisi Kuadrant II. Posisi tersebut memanfaatkan kekuatan yang ada untuk menghadapi ancaman dengan melakukan strategi difersifikasi produk atau pemasaran. Berikut adalah penjelasan turunan startegi tindakan Kuadrant II: Menambah Sub unit bisnis menambah
Sub unit bisnis di dalam rumah tangga usaha, seperti budidaya lele, tanaman produktif yang bisa menambah penerimaan.

1. Difersifikasi produk

Difersifikasi bisa menjadi pilihan strategi yang tepat, dimana kita bisa bermain di produk olahan, seperti ayam karkas, produk olahan ayam siap saji, dan lain-lain.

2. Perlu adanya backup usaha pendukung

Usaha pendukung perlu dilakukan karena dengan adanya usaha pendukung, kerugian bisa saling menutupi atau subsidi silang. Sebagai contoh, apabila ditingkat harga peternak harga sedang jatuh, usaha tersebut bisa bermain di tingkat harga konsumen yang mana harga jual lebih tinggi, contoh: RPH (Rumah Potong Hewan).

4. Perbaikan teknik produksi

Tiga hal yang sangat penting dalam peternakan ayam broiler, yang pertama pemberian pakan, sanitasi kandang, dan vaksin, vitamin, obatobatan. Sanitasi kandang yang didalamnya terdapat faktor sirkulasi udara, perlakuan pengurangan tingkat stress pada DOC selama dalam perjalanan untuk proses pengiriman seperti pemberian air yang dicampur dengan gula merah (Rasyaf, 2008). Hal tersebut bisa mengurangi tingkat kematian atau mortalitas ayam.

5. Bermitra (Mitra usaha)

Bemitra adalah salah satu strategi yang mana pemilik peternakan masih ingin bergerak di bidanng sama dan berada di level yang aman. Calon mitra cukup menyediakan lahan dan 
kandang serta jaminan di atas kerjasama, calon mitra akan disuplai dalam bentuk pakan, DOC, vitamin vaksin dan obat-obatan serta diberikan penyuluhan yang baik dalam berternak dan selalu diawasi penuh oleh mitra inti. Kerjasama lainnya yaitu bermitra antar sesama peternak terutama dalam penyediaan atau pengadaan sarana produksi yang dilakukan secara berkelompok 2) kerjasama antara peternak dengan perusahaan peternakan (poultry shop, pabrik pakan, breeding, pabrik peralatan dan obat-obatan peternakan) dalam bentuk pola Perusahaan Inti Rakyat (PIR). Perusahaan peternakan menyediakan sarana produksi sarana produksi (DOC, pakan dan obat-obatan) dan pemasaran hasil produksi ayam peternak, sedangkan peternak menyediakan lahan, kandang dan tenaga kerja 3) kerjasama antara peternak dengan petani pemilik lahan. Kerjasama ini dapat berupa peternak menyewa lahan milik petani untuk digunakan budidaya jagung atau kontrak pembelian jagung yang ditanam petani dengan peternak (Komalasari, 2008).

\section{Strategi Kelangsungan usaha}

\section{Strategi meningkatkan daya saing}

\section{a. Cari kekuatan pada segmen yang baru}

Apabila sebuah usaha sudah berjalan cukup lama dan mengalami keberhasilan dan kerugian dapat diartikan sedikit banyaknya pengusaha terssebut sudah belajar dari berbagai hal. Keberhasilan merupakan sesuatu yang diharapkan oleh para pengusaha namun mau tidak mau kerugian pun harus bisa diterima karena hal tersebut merupakan konsekuensi seorang pengusaha, oleh karena itu seorang pengusaha harus mempunyai strategi dalam menghadapinya. Pada kasus peternakan peternakan SGF 88, mencari segmen baru di bidang yang sama tapi tidak serupa harus dilakukan oleh perusahaan ini, seperti melakukan ekspansi budidaya ayam petelur, kemudian bergerak ke hilir langsung ditingkat konsumen dimana harga jual lebih tinggi, dapat disubsidi silang untuk menjaga keberlangsungan usaha. Penelitian terdahulu telah membuktikan bahwa usaha peternakan ayam broiler layak untuk dijalankan ketika melakukan pengembangan usaha dengan meningkatkan produktivitas ayam ras petelur (Sianturi \& Sarianti, 2011).

\section{b. Risiko memberikan keuntungan}

Sebuah perusahaan yang sudah mempunyai jam terbang yang tinggi pasti memiliki pengalaman yang cukup banyak, namun dalam setiap usaha pasti berkaitan dengan yang namanya risiko. Namun jika risiko dilihat dari sisi yang berbeda, pengusaha yang cekatan akan dapat melihat sisi positif atau peluang dari risiko tersebut. Risiko dan peluang selalu terjadi dalam waktu bersamaan (Siahaan, 2009). Pada kajian analisis SWOT, terdapat sebuah area dalam sebuah matrik yang disebut Kuadrant I, yang mana area tersebut bersifat agresif memanfaatkan kekuatan dan peluang untuk menguasai pasar dari berbagai sisi. Sifat agresif di kuadrant I memungkinkan mengambil sebuah resiko yang tinggi untuk memperoleh keuntungan yang besar. 


\section{Strategi Keberlangsungan Usaha \\ a. Sinergi antara peran pemerintah selaku pembuat kebijakan serta lembaga pendamping}

Kendala yang sering terjadi dalam sebuah usaha ternak sebagai UKM adalah sumber permodalan. Pemerintah selalu menganjurkan para pelaku ekonomi untuk mengarahkan ke lembaga keuangan dengan dijanjikan kemudahan dalam prosesnya, namun hal tersebut dapat memberikan efek buruk kepada pelaku usaha ternak untuk membiasakan berhutang yang justru nantinya akan membawa kedalam sebuah kehancuran sedikit demi sedikit. Solusi atas permodalan tersebut, pemerintah bisa memberikan kebijakan subsidi permodalan dengan sistem bagi hasil, mencarikan investor kepada pelaku usaha rakyat dengan meyakinkan mereka dengan prospek usaha tersebut. Tentunya kebijakan-kebijakan tersebut harus dilandasi pertimbangan dan persyaratan yang matang.

\section{b. Pemerintah maupun Pemerintah Daerah untuk terus melakukan pembinaan dan pelatihan melalui peningkatan capacity building}

Peran pemerintah sangat penting dalam pembinaan dan pelatihan para UKM, dengan adanya pembinaan dan pelatihan dapat membentuk atau menambah kemampuan para pelaku UKM agar bisa menjadi lebih baik dan siap terjun ke lapangan atau dunia usaha.

\section{SIMPULAN DAN SARAN}

Berdasarkan hasil analisis kelayakan yang dilakukan pada peternakan ayam broiler SGF88 dilihat dari analisis SWOT dan aspek finansial, dapat disimpulkan bahwa pada peternakan ayam broiler SGF88 tidak layak untuk dijalankan. Hal tersebut dapat dilihat $\mathrm{R} / \mathrm{C}$ rasio $=(0,02)$, Net $\mathrm{B} / \mathrm{C}=0,98$, dan tingkat pengembalian modal diperoleh hasil $(52,24)$ bulan, yang artinya tingkat jangka waktu pengembalian tidak ada. Strategi keberlangsungan usaha untuk SGF88, pemilik dianjurkan untuk menambah segmen baru bidang yang sama guna menunjang kerugian pada usaha inti dengan cara melakukan subsidi silang. Melihat sebuah resiko dari berbagai sisi, sehingga muncul peluang dibalik resiko tersebut dan memanfaatkanya untuk memperoleh keuntungan yang besar.

Berdasarkan hasil analisis yang telah dilakukan pada penelitian ini, maka peternakan ayam broiler SGF88 disarankan untuk menambah sub unit bisnis, perlu adanya backup usaha pendukung, difersifikasi produk atau pemasaran, perbaikan teknik produksi dan dengan cara bermitra. Berdasarkan hasil analisis finansial, lebih memperhatikan tingkat kepekaan usaha terhadap perubahan, seperti kenaikan harga pakan dan penurunan harga jual, selain itu peternakan ayam broiler SGF 88 harus lebih memperhatikan efisiensi biaya atau over cost sehingga peternakan ayam broiler SGF88 terus berjalan dan berkembang. 
DAFTAR PUSTAKA

Badan Pusat Statistik. (2018). Populasi Ayam Ras Pedaging menurut Provinsi, 2009-2018 (p. 1). p. 1. Retrieved from https://www.bps.go.id/linkTableDina $\mathrm{mis} / \mathrm{view} / \mathrm{id} / 1034$

Karmidi, J. S. M. (2012). Analisis Kelayakan Usaha Peternakan Ayam Broiler Pola Kemitraan Inti Plasma (Studi Kasus Plasma Agus Suhendar di Desa Patambran, Kecamatan Bogor, Kabupaten Bogor) (Skripsi). Retrieved from https://repository.ipb.ac.id/bitstream/h andle/123456789/56185/H12jsm.pdf? sequence $=11 \&$ isAllowed $=y$

Komalasari, L. (2008). Kelayakan Finansial Peternakan Ayam Broiler Terpadu (Skripsi). https://doi.org/10.1016/j.cell.2009.01. 043

Nurmalina, R., Sarianti, T.,\& Karyadi, A. (2009). Studi Kelayakan Bisnis. Bogor: Departemen Agribisnis Fakultas Ekonomi dan Manajemen Institut Pertanian Bogor.

Rangkuti, F. (2006). Analisis SWOT Teknik Membelah Kasus Bisnis. Jakarta: PT. Gramedia Pustaka Utama.

Rasyaf, M. (2008). Panduan Beternak Ayam Pedaging (1st ed.; A. Anggara, Ed.). Retrieved from https://books.google.co.id/books?id=2 U9AKhisRE0C\&lpg=PP1\&hl=id\&pg $=\mathrm{PA} 30 \# \mathrm{v}=$ onepage $\& \mathrm{q} \& \mathrm{f}=$ false

Saptana. (2013). Dinamika Kemitraan

Usaha Industri Broiler Berdaya Saing. Retrieved from http://www.litbang.pertanian.go.id/bu ku/memperkuat_dayasaing_produk_p e/BAB-V-4.pdf
Saputra, E. E. (2011). Analisis Kelayakan Investasi Peternakan Ayam Broiler Pada Kondisi Risiko (Studi Kasus: Peternakan Rakyat Milik Bapak Marhaya, Kecamatan Nanggung, Kabupaten Bogor, Jawa Barat) (Skripsi). Retrieved from https://www.google.com/url?sa=t\&rct $=\mathrm{j} \& \mathrm{q}=\&$ esrc $=$ s\&source $=$ web $\& \mathrm{~cd}=1 \&$ $\mathrm{cad}=\mathrm{rja} \& u a c t=8 \& v e d=2 \mathrm{ahUKEwiP} 4$ $\mathrm{N}-$

Sq_jmAhUFILcAHdVaBNUQFjAAe gQIBRAC\&url=https $\% 3 \mathrm{~A} \% 2 \mathrm{~F} \% 2 \mathrm{Fre}$ pository.ipb.ac.id\%2Fbitstream $\% 2 \mathrm{~F} 12$ 3456789\%2F49904\%2F1\%2FH11ees. pdf\&usg=AOvVaw1bLOBzHzWI6E$\mathrm{KeB} \_$but-

Setiawan, A. (2016). Analisis Kelayakan Usaha Peternakan Ayam Broiler Di Desa Lulut Kecamatan Klapanunggal Kabupaten Bogor. Retrieved from http://repository.ipb.ac.id/handle/1234 56789/80423

Siahaan, H. (2009). Manajemen Risiko Pada Perusahaan Birokrasi (2 Revisi; R. L. Toruan, Ed.). Retrieved from https://books.google.co.id/books?id=7 R5bDwAAQBAJ\&lpg=PP1\&pg=PR4 $\# \mathrm{v}=$ onepage $\& \mathrm{q} \& \mathrm{f}=$ false

Sianturi, E. C. J., \& Sarianti, T. (2011). Analisis Kelayakan Usaha Ayam Ras Petelur pada Dian Layer Farm di Desa Sukadamai Kecamatan

Darmaga Kabupaten Bogor (Skripsi). Retrieved from https://repository.ipb.ac.id/bitstream/h andle/123456789/53526/H11ecj.pdf?s equence $=11 \&$ isAllowed $=\mathrm{y}$

Sudaryanto, Ragimun, \& Wijayanti, R. R. (2014). Strategi Pemberdayaan UMKM Menghadapi Pasar Bebas Asean. Www.Kemenkeu.Go.Id, 1-32. 
Retrieved from

http://www.perpustakaan.depkeu.go.i

d/FOLDERJURNAL/2014_kajian_pk

em_Strategi Pemberdayaan

UMKM.pdf.

Umar, H. (2007). Studi Kelayakan Bisnis

(3rd ed.). Jakarta: PT. Gramedia

Pustaka Utama.

Fauzi, I., Wibaningwati, D.B., Anggarawati, S.: Strategi usaha ternak mandiri di Desa Cimahpar, Kampung Belentuk, Kecamatan Bogor Utara. (1-14) 